Policy Briefs

Open Access

John Casey*

\title{
Tsars, Task Forces and Standards: The New "IRS"?
}

DOI $10.1515 / \mathrm{npf}-2015-0036$

Abstract: Institutional processes for regulating government-nonprofit relations in the U.S. are experiencing substantial growth, particularly at the state level. First, cabinet-level nonprofit "tsars" are being appointed by state governments as point persons for communication and coordination with nonprofits. Second, high-level cross-sector task forces are being established to examine the current relations between the sectors and to recommend reforms in regulatory and oversight processes. Third, nonprofit industry associations are developing statements of operating standards that seek to promote greater discipline in operations. These processes are potentially harbingers of the creation of new institutionalized relationship systems (IRS). This paper examines the emergence of these new institutional arrangements, analyzes their short-term impacts and speculates about their durability.

Keywords: nonprofit-government relations

\section{Introduction}

Institutional processes for regulating government-nonprofit relations in the U.S. are experiencing substantial growth, particularly at the state level. First, cabinetlevel nonprofit "tsars" are being appointed by state governments as point persons for communication and coordination with nonprofits. Second, high-level crosssector task forces are being established to examine the current relations between the sectors and to recommend reforms in regulatory and oversight processes. Third, nonprofit industry associations are developing statements of operating standards that seek to promote greater discipline in operations. These processes are potentially harbingers of the creation of new institutionalized relationship systems (IRS). This paper examines the emergence of these new institutional arrangements, analyzes their short-term impacts and speculates about their durability.

*Corresponding author: John Casey, Center for Nonprofit Strategy and Management, School of Public Affairs, Baruch College, City of University of New York (CUNY), New York, USA, E-mail: john.casey@baruch.cuny.edu 


\section{Government-Nonprofit Relations in the U.S.}

These emerging institutional arrangements are the U.S. manifestation of a broader international trend to more deliberate relations between governments and nonprofits. Despite very different histories of nonprofit development and current operating models, countries as diverse as Australia, Estonia, France, Spain and Sweden have all recently developed formal policy documents for cooperation, commonly known as compacts. Many others, while not signing formal compacts, have strengthened deliberate relations through the establishment of new coordinating structures (Reuter, Wijkström, and von Essen 2012).

In the U.S. there are currently no broad, sector-to-sector agreements that would be the direct equivalents of the compacts that have emerged in numerous other countries (Casey 2015a, 2015b). The dominant political and cultural norms continue to be the independence of private voluntary endeavors, and both government and nonprofits seem to be somewhat wary of entering into such agreements. The key role played by private philanthropy means that the nonprofit sector spends more organizational effort cultivating relationships with the business sector than with government. Various structural realities also make such agreements difficult to achieve at national level, as much of the oversight of nonprofits and the regulation of program funding is devolved to the 50 states. In most states, the Governors, who oversee program implementation through the line agencies, and the Attorneys-General, who generally regulate nonprofits, are both directly elected and so have separate, and often conflicting, political bases and agendas.

While these factors may explain why there have not been sector-wide agreements, they should not be interpreted as evidence that U.S. exceptionalism has provided alternative pathways to resolve the concerns that have emerged in other countries. On the contrary, the Aspen Institute $(2002,4)$ noted that "the relationship between government and the nonprofit sector has grown without a great deal of attention or focus" and that ambiguity exists about how their relationship should best evolve. Grønbjerg and Salamon (2012) decried the poor state of relations between the sectors and recommended a new paradigm of government-nonprofit interaction in which nonprofits acknowledge the legitimate performance requirements of government, and government acknowledges the advocacy responsibilities of nonprofits and its own obligation to provide greater stability in public funding for nonprofits.

The response to these concerns is a rewriting of the social pact between the sectors (Young 2006) at national, state and local levels. At the national level, the need for better relations tends to be couched in terms of policy input, while at state and local levels, where there is a more coalface relationship concerning 
service delivery, the push for better relations are framed more as the need to ensure more effective and efficient government contracting process and nonprofit compliance with performance criteria. The mutual dependence between the sectors has resulted in dynamics that increasingly favor more horizontal, collaborative relations, but hierarchical structures continue to be central, particularly in times of budget shortfalls when public managers have less discretion to negotiate policy and programmatic decisions (Saidel 2011).

Government regulation and other oversight of the operations of nonprofits is increasingly accepted by the nonprofit sector as the price to be paid for funding opportunities and fiscal advantages, as well as a response to possible security concerns generated by post 9-11 scrutiny. Recent changes in Internal Revenue Service regulations, which extended at least minimal tax reporting requirement to all nonprofits, considerably reduced the number of registered organizations as inactive ones failed to meet submission deadlines and so lost their nonprofit status. In most other areas of nonprofit operations, external oversight is increasing through the pressure for performance measurement and transparency as well as through the more aggressive pursuit of malfeasance in nonprofits. Many localities are also seeking a greater financial contribution from large nonprofits that are exempt from most taxes, but still consume considerable local resources. A number of cities are negotiating payments-in-lieu-of-taxes (PILOTs) from large health, education and social service nonprofits.

Increasing interdependence means that there are diminishing domains of truly separate activity for the two sectors. What was once the domain of government is increasingly being outsourced to, or subsidized by, nonprofits and what was once the domain of private nonprofit initiative is increasingly regulated by governments. While the closer relations appear to have widespread support in government and the nonprofit sectors, some commentators scorn the "fawning" between the sectors and question whether the relationship is becoming "too close for comfort" (Hudson Institute 2010; Paletta 2010).

\section{Federal Trends}

An interest in strengthening relationships between governments and nonprofits has resurfaced over the past few years in the U.S. Government agencies have more explicitly recognized the contributions that nonprofit organizations make to society and have increased their efforts to promote the sector and to build nonprofit capacity. Industry associations and leadership organizations in the nonprofit sector have been gaining momentum as they build connections, 
cohesion, and capacity within the sector. With both governments and nonprofits coming to the table with renewed energy and a clearer focus, there appears to be a greater willingness to work collaboratively and to leverage their collective capacity.

There have been past attempts at creating closer cooperation, but lack of interest and political will, particularly in economic boom times, as well as the absence of clear institutional pathways appear to have hampered their development and restricted efforts to relatively isolated and smaller scale initiatives. In the 1970s, the Filer Commission recommended that Congress create a permanent commission on nonprofits "to serve actively in close consultation with government as an ombudsman in the protection of the interests of the private nonprofit sector" (Filer Commission, 1975, 5). While the hopes of the advocates for this new commission were thwarted in the transition to the Carter administration and it never materialized, the work of the Filer Commission led to the creation in 1980 of the first sector-wide nonprofit industry association, the Independent Sector (Hall 2010), and the push for new coordination structures has never left the policy agenda. The Filer recommendation for a permanent commission has resurfaced periodically, often in the form of calls to create a federal agency for nonprofits that would match the work done by the Small Business Administration (McCollum 2010; Sherlock and Gravelle 2009).

In the twenty-first Century there have been various national initiatives to develop a stronger voice for nonprofits and sector-wide principles for collaborating with government, including the Aspen Institute's The Nonprofit Sector and Government: Clarifying the Relationship (Aspen Institute 2002) and the Declaration for America's Nonprofit and the Nonprofit Constitution sponsored by the National Council of Nonprofits (Nonprofit Congress 2007). In March 2009, a “call to action” signed by more than 400 nonprofit CEOs and academics was published as the Forward Together Declaration (JHUCCS 2009). The Forward Together Declaration states that it is time to "renew the compact" with the nonprofit sector (note that compact is used here in the conceptual sense and does not refer to a specific past document), and calls for the establishment of a Commission on Cross-Sector Partnerships and the development of a set of Partnership Principles. The text of the Forward Together Declaration invokes many of the same discourses that have fostered the establishment of new structures of deliberate relations in other countries.

In June 2010 the Nonprofit Sector and Community Solutions Act (H.R. 5533) was introduced into the U.S. 111th Congress. According to its principal sponsor, Representative Betty McCollum (D-MN), the aim was "to improve the relationship between the federal government and nonprofits ... by making the federal government a more productive partner with nonprofit organizations” (McCollum 2010). Among other measures, the act sought to establish a cross-sector Council on 
Nonprofit Organizations and Community Solutions that would bring together representatives from government, nonprofits and business, and a federal government Interagency Working Group on Nonprofit Organizations that would evaluate recommendations from the new Council and coordinate policymaking relating to nonprofits. The proposed act languished in a House Committee and died there at the end of the 2010 111th Congress, but nonprofit industry groups continue to call for the enactment of its key elements.

\section{State Trends}

The federal architecture of the U.S. polity make national solutions difficult, so much of the negotiation over policy and the majority of contracting process take place at subnational levels. State institutional arrangements for government-nonprofit relations have seen substantial growth in the last decade. Cabinet-level nonprofit tsars are being appointed as point persons for communication and coordination with nonprofits. Many states are also establishing ad-hoc or permanent cross-sector task forces to examine relations between governments and to recommend reforms in regulatory and oversight processes. And the sector itself is generating statements of operating standards that serve to strengthen the political bargaining positions of nonprofit organizations. These arrangements focus primarily on human services procurement process, but they also aspire to the broader goals of strengthening the wider nonprofits sector in their jurisdiction and to improve collaborative relations between government, business and nonprofit sectors. They seek to reduce uncertainties and to smooth the tensions between governments and nonprofits generated by attempting to balance the realities of monopsony principal-agent contracting with aspirations of relational contracting.

\section{Tsars}

In 2003, Governor Granholm of Michigan established the Michigan Office of Foundation Liaison to broker strategic partnerships between the state and foundations, and in 2008 Governor Schwarzenegger of California appointed a Secretary for Service and Volunteering to improve coordination of volunteer efforts between the state's agencies (both states claim in various press releases and descriptions of the offices that theirs was the first cabinet-level position for nonprofits in the nation). There is no accurate documentation of the number of such positions that have been created throughout the U.S. but their numbers continue to grow, including the 2011 creation of the Connecticut cabinet position 
of Nonprofit Liaison and head of the Community Nonprofit Human Services Cabinet and the 2012 appointment of a New York State Interagency Coordinator for Not-for-Profit Services. Their powers and authority vary considerably (some probably do not merit the appellation "tsar"), but the establishments of these new posts appear to be significant markers of a recalibration in relations.

\section{Task Forces}

Task Forces to foster cross-sector relations have been established in Connecticut, Hawaii, Illinois, Maine, Maryland, New Jersey, New York, North Carolina and Texas (Miltenberger et al. 2014). No two are exactly alike in their composition, goals and operations, but all the Task Forces convene representatives from state government agencies and nonprofit organizations to coordinate discussions on reforms. The National Council of Nonprofits is providing guidance and support to the state Task Forces on the presumption that they potentially provide the mechanism to establish more collaborative relationships based on trust, respect, and shared values (National Council of Nonprofits 2013).

The Task Forces have been established through varying pathways - legislation, executive order, executive agency, or Attorney General (Table 1).

Table 1: State Task Forces on Contracting.

Legislative

Governor Executive Order

Executive Agency

Attorney General
Connecticut, Hawaii, Illinois, Maryland, Texas

New Jersey

Maine, North Carolina

New York

Source: Miltenberger et al. 2014.

The various Task Force Reports contain similar recommendations, which include the establishment of more permanent liaison structures, increased communication between government agencies in the design of contracting and evaluation process, and the sharing of good practices (Miltenberger et al. 2014).

\section{Operating Standards Documents}

Increasingly prominent are documents developed by state nonprofit industry associations which seek to set operating standards for nonprofits. The documents vary from state to state, but have the common thread of establishing rubrics for principles of practice. Examples include: 
- The California Association of Nonprofits developed Ensuring Nonprofit Integrity, an assessment tool for accountability that seeks to "reframe the public discussion about nonprofit practice and the role nonprofits play in society" (California Association of Nonprofits 2007).

- The Alliance of Arizona Nonprofits has published One Voice Arizona: A Nonprofit Agenda (Alliance of Arizona Nonprofits 2008), which promotes a common vision of the nonprofit sector based on strategies such as "speak with one voice," and Toward Common Sense Contracting: What Taxpayers Deserve (Alliance of Arizona Nonprofits 2014), which promotes contracting reform.

- The Illinois Donors Forum published the Fair and Accountable: Partnership Principles for a Sustainable Human Services System (Donors Forum 2010), which has subsequently been adopted in whole or part by other states working on contracting reform.

- The Colorado Nonprofit Association has published three editions of its Principles \& Practices for Nonprofit Excellence in Colorado which seeks to strengthen capacity and accountability of nonprofits in the state (Colorado Nonprofit Association 2015).

These documents are generally developed by the state nonprofit association in collaboration with the state government regulatory agency, usually the Attorney General.

\section{Policy Implications}

Are the current U.S. dynamics simply an isomorphic blip, or harbingers of enduring structural changes? The new structures and process are seen as heralding a new era in the evolving relationship between governments and nonprofits, but also as necessary peace treaties between sectors that have been at odds due to previous excesses of the contracting and competitive tendering approaches, or because of a history of mutual distrust and political rivalry, and as much needed coordination mechanisms for interactions potentially beset by fragmentation and inefficiencies. Changes in government often derail specific initiatives, but the various forms of these new deliberate relations are likely to continue as a central feature of government-nonprofit relations in years to come. Whatever the future holds for any individual initiative, the increased intensity of transactions between the sectors continues to create institutional pressure for more tsars, task forces and standards documents more that can reduce uncertainties. Potentially they can 
generate more equitable dialogues between the sectors, but equally can contribute to the establishment of new institutional regulatory systems (IRS) that reinforces the oversight of the other IRS.

Acknowledgement: This briefing paper is based on materials earlier published in Casey 2015b and Miltenberger et al. 2014. I would like to acknowledge and thank Lauren Miltenberger and Beth Bowsky for their contribution to this research.

\section{References}

Aspen Institute. 2002. The Nonprofit Sector and Government: Clarifying the Relationship. Washington: Aspen Institute. Accessed 23 February 2010. http://www.aspeninstitute.org/ publications/nonprofit-sector-and-government-clarifying-relationship.

Alliance of Arizona Nonprofits. 2008. One Voice Arizona: A Nonprofit Agenda. Accessed 3 February 2010. http://www.arizonanonprofits.org/onevoice.

Alliance of Arizona Nonprofits. 2014. Toward Common Sense Contracting: What Taxpayers Deserve. Accessed 19 March 2015. https://www.councilofnonprofits.org/sites/default/ files/documents/toward-common-sense-contracting-what-taxpayers-deserve.pdf.

California Association of Nonprofits. 2007. Ensuring Nonprofit Integrity. Accessed 19 March 2015. http://www.unitedwaymcca.org/sites/unitedwaymcca.oneeach.org/files/ NonprofitAccountabilityAssessmentTool.pdf.

Casey, J. 2015a. The Nonprofit World: The Rise of Civil Society and the Nonprofit Sector. Boulder: Lynne Reimer Press.

Casey, J. 2015b. "Deliberate Relations Between Governments and Nonprofits." In Government and the Non-Profit Sector, edited by J. Brothers Farnham, Surrey: Gower Publishing.

Colorado Nonprofit Association. 2015. Principles \& Practices for Nonprofit Excellence in Colorado. Accessed 19 March 2015. http://www.coloradononprofits.org/help-deskresources/principles-practices/.

Donors, Forum. 2010. Fair and Accountable: Partnership Principles for a Sustainable Human Service System. Chicago: Donors Forum. https://donorsforum.org/tools-resources/fairaccountable.

Filer Commission. 1975. Giving in America: Toward a Stronger Voluntary Sector: Report of the Commission on Private Philanthropy and Public Needs. Washington: Commission on Private Philanthropy and Public Needs.

Grønbjerg, and L. M. Salamon. 2012. "Devolution, Marketization, and the Changing Shape of Government-Nonprofit Relations." In The State of Nonprofit America, edited by L. M. Salamon. Washington: Brookings Institution Press.

Hall, P. D. 2010. "Historical Perspectives on Nonprofit Organizations in the United States." In The Jossey-Bass Handbook of Nonprofit Leadership and Management, edited by D. Renz. San Francisco: Jossey-Bass.

Hudson Institute. 2010. Too Close for Comfort? Obama and the Foundations. Accessed 3 February 2014. http://www.hudson.org/index.cfm? fuseaction $=$ hudson_upcoming_events\&id $=749$. 
JHUCCS (Johns Hopkins University Center for Civil Society). 2009. The Forward Together Declaration. (unpublished).

McCollum, B. 2010. Giving the US Nonprofit Sector a Seat at the Federal Table. Accessed 29 July 2010. http://thehill.com/blogs/congress-blog/campaign/109795-giving-the-us-nonprofitsector-a-seat-at-the-federal-table-rep-betty-mccollum.

Miltenberger, L., J. Casey, B. Bowsky, and A. Bittner. 2014. Partnerships for Care and Caring for Partnerships: State Nonprofit-Government Task Forces on Collaboration (unpublished manuscript).

National Council of Nonprofits. 2013. Government-Nonprofit Task Forces. Accessed 19 March 2015. https://www.councilofnonprofits.org/trends-policy-issues/government-nonprofittask-forces.

Nonprofit Congress. 2007. About the Nonprofit Congress. Accessed 5 December 2007. http:// www.nonprofitcongress.org/?q=about.

Paletta, A. 2010. The Fawning of the Foundations as Philanthropists Pledge Allegiance to the Administration's Political Agenda. Wall St Journal. Accessed 30 May 2010. http://www.wsj. com/articles/SB10001424052748704471204575210751254846816.

Reuter, M., F. Wijkström, and J. von Essen. 2012. "Policy Tools or Mirrors of Politics. Government-Voluntary Sector Compacts in the Post-Welfare State Age." Nonprofit Policy Forum 3 (2):Article 2, ISSN (Online) 2154-3348.

Saidel, J. R. 2011. "Proxy-Partnership Governance Continuum: Implications for Nonprofit Managers." In The State of Public Administration: Issues, Challenges, and Opportunities, edited by D. C. Menzel and H. L. White. Armonk, NY: M.E. Sharpe.

Sherlock, M. F., and J. G. Gravelle. 2009. An Overview of the Nonprofit and Charitable Sector. RS Report for Congress 7-5700. Washington: Congressional Research Office. Accessed 3 February 2010. www.fas.org/sgp/crs/misc/R40919.pdf

Young, D. R. 2006. “Complementary, Supplementary, or Adversarial?” In Nonprofits and Government: Collaboration and Conflict, edited by E. T. Boris and C. E. Steuerle. Washington: Urban Institute Press. 